\title{
Porin alteration and active efflux: two in vivo drug resistance strategies used by Enterobacter aerogenes
}

\author{
Monique Mallea, Jacqueline Chevalier, Charleric Bornet, Annie Eyraud, \\ Anne Davin-Regli, Claude Bollet and Jean-Marie Pagès
}

Author for correspondence: Jean-Marie Pagès. Tel: +334913245 87. Fax: + 33491324606 . e-mail : Jean-Marie.Pages@medecine.univ-mrs.fr

Enveloppe Bacterienne, Antibiotiques et Colonization, CJF 96-06 INSERM and EA 2197, Faculté de Médecine, 27 Boulevard Jean Moulin, 13385 Marseille Cedex 05, France

\begin{abstract}
Enterobacter aerogenes is among the five most frequently isolated nosocomial pathogens in France, and this bacterium also shows increasing multidrug resistance. In this study, various $E$. aerogenes strains isolated from hospital units were characterized for their outer-membrane proteins, antibiotic susceptibilities (inhibition diameters and MICs) and resistance mechanisms associated with modification of envelope permeability (porin alteration and active efflux). Diminished outer-membrane permeability due to porin alterations was found in conjunction with the expression of an enzymic barrier in resistant isolates. Interestingly, changes in the functional expression of porins appeared to play a special role in susceptibility to cefepime. An active efflux to quinolones was also identified. Simultaneous changes in envelope permeability, i.e. a porin deficiency (in) and an efflux mechanism (out), were clearly evident in two clinical strains.
\end{abstract}

Keywords: Enterobacter aerogenes, multidrug resistance, $\beta$-lactamase, efflux, membrane permeability

\section{INTRODUCTION}

The emergence of bacterial resistance to several structurally unrelated antibiotics complicates the treatment of nosocomial infections. This adaptive response is involved in the dissemination of bacteria in intensive care units, hospital outbreaks and changes in patients' flora (Bergogne-Berezin et al., 1993; Emori \& Gaynes, 1993; Thornsberry, 1995; Vincent et al., 1995). In addition, antibiotic resistance markedly increases morbidity and the costs of therapy (Cassell, 1995; Gibbons, 1992). In Enterobacteriaceae, resistance to $\beta$-lactam antibiotics is frequently associated with the production of hydrolytic enzymes and membrane alterations, leading to a reduction in the intracellular concentration of active compound (Bradford et al., 1997; Charrel et al., 1996; Lee et al., 1991; Rice et al., 1993). Several groups recently described a mechanism relating to other antibiotics whereby bacteria lower intracellular drug concentrations by a process of active efflux. Efflux pumps explain the multidrug resistance phenotype (Mdr). The presence of Mdr or similar systems has been reported in

Abbreviation: CCCP, carbonyl cyanide $m$-chlorophenylhydrazone.
Enterobacteriaceae (Alekshun \& Levy, 1997; George, 1996; Nikaido, 1996), showing the general conservation of this active protection system against toxic compounds (Ariza et al., 1995; Gambino et al., 1993; George et al., 1995; Ma et al., 1995; Okusu et al., 1996). Drug efflux can be expressed conjointly to a reduction in drug uptake: examples of a drastic decrease in outer-membrane porins have been reported, pointing to a nodal site in the regulation cascade of the Mdr process (Cohen $e t$ al., 1988; Gambino et al., 1993; George et al., 1995). The spread of several resistance mechanisms and the modulation of the different bacterial responses to antibiotic therapy call for studies of multidrug resistance systems, their identification and their prevalence in strains isolated from hospital units.

Enterobacter aerogenes is one of the most frequently identified nosocomial pathogens in France (Arpin et al., 1996; Davin-Regli et al., 1996), yet little information is available for E. aerogenes strains with respect to the presence of the Mdr phenotype or their involvement in hospital outbreaks. For this purpose, we defined an $E$. aerogenes population harbouring high cross-resistance against a number of standard antibiotics. We studied such clinical strains for resistance strategies involving an alteration of outer-membrane porins that can be, but 
does not have to be, associated with an efflux mechanism.

\section{METHODS}

Bacterial strains and growth conditions. During a 6-month period, about 50 strains of Enterobacter spp. (E. aerogenes, Enterobacter cloacae and Enterobacter hormaechei) were isolated in the South hospital of Marseille (France) from a variety of clinical specimens (respiratory tract, secretions, suppurations, blood, etc., excluding the urinary tract) and were identified by use of the API 20E system (bioMerieux). These isolates had shown resistance against several $\beta$-lactam antibiotics in the Walkaway Microscan micromethod (Dade). This analysis focused on the $27 \mathrm{E}$. aerogenes isolates. The $E$. aerogenes type strain ATCC 13048 was used as reference. Escherichia coli BZB1107 (ompF:: Tn $\left.5 \mathrm{Km}^{\mathrm{r}}\right)$ and the plasmid pMY150 encoding OmpC have been described elsewhere (Fourel et al., 1993; Nogami et al., 1985). Bacteria were routinely grown in Luria-Bertani (LB) or Mueller-Hinton (MH) broth at $37^{\circ} \mathrm{C}$.

Antibiotic susceptibility tests. We used the standard disk diffusion method on $\mathrm{MH}$ agar (bioMérieux). According to growth inhibition zones, bacterial strains were classified as susceptible, intermediate or resistant, in keeping with the indications of the Antibiogram Committee of the French Society for Microbiology (Acar et al., 1994). For the determination of MICs, approximately $10^{6}$ cells were inoculated into $1 \mathrm{ml} \mathrm{MH}$ broth containing twofold serial dilutions of each antibiotic, directly and in the presence of clavulanic acid $\left(2 \mu \mathrm{g} \mathrm{ml}^{-1}\right)$. MICs of imipenem were determined directly and in the presence of EDTA $(1 \mathrm{mM})$. The results were read after $18 \mathrm{~h}$ at $37^{\circ} \mathrm{C}$ (Charrel et al., 1996).

$\boldsymbol{\beta}$-Lactamase detection. Bacteria were grown in LB broth at $37{ }^{\circ} \mathrm{C}$, harvested in the late-exponential phase and disrupted by sonication (five bursts of $15 \mathrm{~s}$, separated by cooling periods of $15 \mathrm{~s}$ ) in $100 \mathrm{mM}$ phosphate buffer, $\mathrm{pH} 7 \cdot 0$. Crude extracts were obtained after centrifugation at $30000 \mathrm{~g}$ for $45 \mathrm{~min}$ at $4{ }^{\circ} \mathrm{C}$. Protein content was quantified with the micro bicinchoninic acid protein assay (BCA Pierce). $\beta$-Lactamase activity was determined spectrophotometrically (Shimadzu UV-1605) at $486 \mathrm{~nm}$ with nitrocefin (Oxoid) as substrate. One milliunit of $\beta$-lactamase was defined as the amount of enzyme that hydrolysed $1 \mathrm{nmol}$ nitrocefin $\min ^{-1}(\mathrm{mg} \text { protein })^{-1}$ at $25^{\circ} \mathrm{C}$. The level of $\beta$-lactamase induction was evaluated for cultures with subinhibitory concentration of imipenem (one-quarter of respectively determined MICs of imipenem).

Measurement of norfloxacin accumulation. Exponentialphase bacteria in LB broth were removed by centrifugation and washed once in $50 \mathrm{mM}$ sodium phosphate buffer (SPB), $\mathrm{pH} 7 \cdot 0$. Pellets were suspended in the same buffer to a density of $2 \times 10^{10}$ c.f.u. $\mathrm{ml}^{-1}$ and kept at $37^{\circ} \mathrm{C}$ for no more than $30 \mathrm{~min}$ before use. To de-energize the bacteria, $50 \mu \mathrm{M}$ carbonyl cyanide $m$-chlorophenylhydrazone (CCCP) was added $10 \mathrm{~min}$ before the radiolabelled antibacterial agent. Assays were initiated by adding $\left[{ }^{14} \mathrm{C}\right]$ norfloxacin $(10 \mu \mathrm{g} \mathrm{m})^{-1}$, $10^{10}$ c.p.m. $\mathrm{ml}^{-1}$ ), a gift from Merck Sharp \& Dohme Laboratories. Samples $(100 \mu \mathrm{l})$ were removed at set intervals and immediately filtered through $0.45 \mu \mathrm{m}$ Whatman GF/C filters pre-soaked in SPB, then washed twice with $5 \mathrm{ml}$ cold SPB. The filters were dried at $80^{\circ} \mathrm{C}$ and the radioactivity was measured in a Beckman scintillation spectrophotometer. Control samples were run under identical conditions. The protein concentration was routinely determined with the BCA protein assay.
SDSPAGE and immunodetection. Exponential-phase bacteria in LB broth were pelleted and solubilized in boiling buffer at $96^{\circ} \mathrm{C}$. Samples $\left(\mathrm{OD}_{600} 0.02\right)$ were loaded on SDS-polyacrylamide gels ( $10 \%$ polyacrylamide, $0 \cdot 1 \%$ SDS) as described previously (Simonet et al., 1996), then electrotransferred to nitrocellulose membranes (Mallea et al., 1995; Simonet et al., 1996). An initial saturating step with Tris-buffered sodium (TBS; $50 \mathrm{mM}$ Tris/ $\mathrm{HCl}, 150 \mathrm{mM} \mathrm{NaCl}, \mathrm{pH} \mathrm{8)} \mathrm{containing}$ $10 \%$ bovine serum was carried out overnight at $4^{\circ} \mathrm{C}$. The nitrocellulose membranes were then incubated in TBS containing $10 \%$ bovine serum and $0.2 \%$ Triton X-100 for $2 \mathrm{~h}$ at room temperature in the presence of polyclonal antibodies directed against denaturated $E$. coli porins $(\mathrm{OmpF}$ and OmpC), against OmpA or OmpX. After four washings in the same buffer, the detection was then performed with alkalinephosphatase-conjugated AffinitiPure goat anti-rabbit IgG antibodies (Jackson ImmunoResearch). The polyclonal antibodies directed against porin monomers and OmpA have been described elsewhere (Bolla et al., 1987; Simonet et al., 1996) and the polyclonal antipeptide antibodies directed against OmpX were obtained as a commercial preparation from Neosystem.

\section{RESULTS}

\section{$\boldsymbol{\beta}$-Lactam susceptibility}

The majority of strains showed a resistance to cefadroxil, aztreonam, cefotetan and ceftazidime (Table 1). In contrast, strains 2 and 19 were the most susceptible to cefotetan, moxalactam and cefepime. Strains 3,5 and 27 were highly resistant to cefepime $\left(64 \mu \mathrm{g} \mathrm{ml}^{-1}\right)$ and moxalactam $\left(>128 \mu \mathrm{g} \mathrm{ml}^{-1}\right.$ ) relative to other isolates collected during the same period. Clavulanic acid restored only partially the aztreonam/ceftazidime susceptibilities of strains 3, 5,7 and 27 compared to most of the other strains (Table 2). As in a previous analysis of $E$. aerogenes isolates, imipenem susceptibility was distinct from cephalosporin susceptibility (Charrel et al., 1996). In this study, strain 27 was intermediate to imipenem with the MIC $\left(8 \mu \mathrm{g} \mathrm{ml}^{-1}\right)$ higher than it was reported for the other strains. The presence of clavulanic acid or EDTA had no effect on MICs of imipenem for the strains with $\mathrm{MIC}>1 \mu \mathrm{g} \mathrm{ml}^{-1}$.

\section{Detection of outer-membrane proteins}

Fig. 1 (upper part) illustrates the distribution of the $E$. aerogenes strains as regards labelling with polyclonal antibodies directed against the $\mathrm{OmpC}$ monomer. The immunorelated porin was detected in all but two of the isolates (strains 5 and 27). Similar results were obtained with polyclonal antibodies directed against the $\mathrm{OmpF}$ monomer (data not shown). Strains 5 and 27 showing strong cross-resistance against $\beta$-lactam compounds had a porin-deficient phenotype. In contrast, strain 3 , despite a similar level of moxalactam and cefepime resistance, labelled positively with the anti-porin monomer antiserum.

It has been reported that some modified bacterial porins (chimeric or mutated) have reduced thermal stability (Fourel et al., 1993; Nogami et al., 1985). We thus analysed the stability of the porins from strains 2,3 and 
Table 1. Susceptibility of the $E$. aerogenes isolates to various $\beta$-lactam antibiotics

IPM, imipenem; CFT, cefadroxil; ATM, aztreonam; MOX, moxalactam; FEP, cefepime; CAZ, ceftazidime; CTT, cefotetan. Values are means of three independent determinations. ND, Not determined.

\begin{tabular}{|c|c|c|c|c|c|c|c|}
\hline \multirow{2}{*}{$\begin{array}{l}\text { E. aerogenes } \\
\text { strain }\end{array}$} & \multicolumn{5}{|c|}{$\operatorname{MIC}\left(\mu \mathrm{g} \mathrm{ml}^{-1}\right)$} & \multicolumn{2}{|c|}{$\begin{array}{l}\text { Inhibition } \\
\text { diameter } \\
(\mathrm{mm})\end{array}$} \\
\hline & IPM & CFT & ATM & MOX & FEP & $\mathrm{CAZ}$ & CTT \\
\hline 1 & 1 & $>512$ & $\geqslant 128$ & 8 & 4 & 6 & 6 \\
\hline 2 & $0 \cdot 06$ & $>512$ & $\geqslant 128$ & 1 & 2 & 6 & 20 \\
\hline 3 & 4 & $>512$ & $\geqslant 128$ & $>128$ & 64 & 6 & 6 \\
\hline 4 & 1 & $>512$ & $\geqslant 128$ & 64 & $8 / 16$ & 6 & 6 \\
\hline 5 & 4 & $>512$ & $\geqslant 128$ & $>128$ & 64 & 6 & 6 \\
\hline 6 & 1 & $>512$ & $\geqslant 128$ & 32 & 4 & 6 & 6 \\
\hline 7 & 2 & $>512$ & $\geqslant 128$ & 16 & 8 & 6 & 6 \\
\hline 8 & 1 & $>512$ & $\geqslant 128$ & 8 & 8 & 6 & 6 \\
\hline 9 & 1 & $>512$ & 64 & 16 & 4 & 6 & 6 \\
\hline 11 & 2 & $>512$ & 128 & 64 & 4 & 6 & 6 \\
\hline 12 & 1 & $>512$ & 128 & 16 & 4 & 6 & 6 \\
\hline 14 & 1 & $>512$ & 128 & 32 & $8 / 16$ & 6 & 6 \\
\hline 15 & 2 & $>512$ & $>256$ & 32 & 8 & 6 & 6 \\
\hline 16 & 1 & $>512$ & 128 & 8 & 4 & 6 & 6 \\
\hline 17 & 1 & $>512$ & 64 & 8 & 4 & 6 & 6 \\
\hline 18 & 1 & $>512$ & 256 & 16 & $8 / 16$ & 6 & 6 \\
\hline 19 & 0.5 & $>512$ & 32 & 0.5 & 1 & 14 & 20 \\
\hline 20 & 1 & $>512$ & 128 & 16 & 4 & 6 & 6 \\
\hline 21 & 0.5 & $>512$ & 256 & 16 & 4 & 6 & 6 \\
\hline 22 & 2 & $>512$ & $>256$ & 16 & 4 & 6 & 6 \\
\hline 23 & 1 & $>512$ & $>256$ & 8 & 4 & 6 & 6 \\
\hline 25 & 1 & $>512$ & 128 & 32 & 4 & 6 & 6 \\
\hline 26 & 0.5 & $>512$ & 128 & 16 & 4 & 6 & 6 \\
\hline 27 & 8 & $>512$ & 256 & $>128$ & 64 & 6 & 6 \\
\hline 28 & 1 & $>512$ & 128 & 8 & 4 & 6 & 6 \\
\hline 29 & 0.5 & $>512$ & 64 & 8 & 4 & 6 & 6 \\
\hline 30 & 1 & $>512$ & 128 & 16 & 4 & 6 & 6 \\
\hline ATCC 13048 & 1 & ND & 2 & 64 & 1 & 30 & 22 \\
\hline
\end{tabular}

Table 2. $\beta$-Lactamase production by seven $E$. aerogenes strains before and after imipenem induction and effect of clavulanic acid on the sensitivity of strains to ceftazidime and aztreonam

\begin{tabular}{|c|c|c|c|c|c|}
\hline \multirow{2}{*}{$\begin{array}{l}\text { E. aerogenes } \\
\text { strain }\end{array}$} & \multicolumn{2}{|c|}{$\begin{array}{c}\beta \text {-Lactamase activity } \\
{\left[\mathrm{mU}(\mathrm{mg} \text { protein })^{-1}\right]}\end{array}$} & \multicolumn{3}{|c|}{$\operatorname{MIC}\left(\mu \mathrm{g} \mathrm{ml}^{-1}\right)^{*}$} \\
\hline & Basal & $\begin{array}{c}\text { After } \\
\text { induction }\end{array}$ & ATM/CLA & $\mathrm{CAZ}$ & CAZ/CLA \\
\hline 2 & 50 & 34 & $<2$ & 64 & 4 \\
\hline 3 & 930 & 7180 & 128 & $>512$ & 128 \\
\hline 5 & 1460 & 3930 & 64 & $>512$ & 256 \\
\hline 7 & 420 & 2590 & 64 & $>512$ & 256 \\
\hline 19 & 420 & 390 & $<2$ & 1 & 1 \\
\hline 27 & 1160 & 9090 & 128 & $>512$ & 256 \\
\hline ATCC 13048 & 120 & 980 & $<2$ & 1 & 1 \\
\hline
\end{tabular}

* ATM, aztreonam; CAZ, ceftazidime; CLA, clavulanic acid $\left(2 \mu \mathrm{g} \mathrm{ml}^{-1}\right)$. 


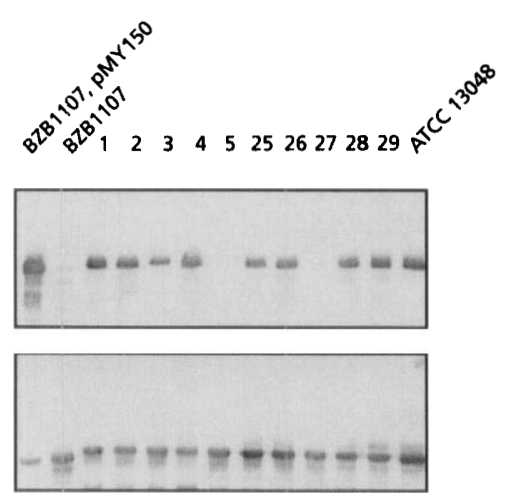

Fig. 1. Immunodetection of $E$. aerogenes outer-membrane proteins. Immunostaining was carried out with polyclonal antibodies directed against the $\mathrm{OmpC}$ monomer (upper part) or OmpA (lower part). BZB1107, pMY150 and BZB1107 E. coli strains with or without the plasmid pMY 150 encoding OmpC; $E$. aerogenes ATCC $13048 ; 1-5$ and $25-29$, E. aerogenes clinical strains. Only the relevant part of the blot is shown.

\section{Table 3. Porin thermostability in E. aerogenes isolates}

Bacterial cell pellets were solubilized at various temperatures $\left(55-70^{\circ} \mathrm{C}\right)$. Detection was carried out with antisera directed against $E$. coli porin monomers. T, Trimer; M, monomer; NP, no porin synthesized.

\begin{tabular}{|lcccc|}
\hline $\begin{array}{l}\text { E. aerogenes } \\
\text { strain }\end{array}$ & \multicolumn{5}{c|}{ Temperature $\left({ }^{\circ} \mathrm{C}\right)$} \\
\cline { 2 - 5 } & $\mathbf{5 5}$ & $\mathbf{6 0}$ & $\mathbf{6 5}$ & $\mathbf{7 0}$ \\
\hline 2 & $\mathrm{~T}$ & $\mathrm{~T}$ & $\mathrm{~T}$ & $\mathrm{M}$ \\
3 & $\mathrm{~T}$ & $\mathrm{M}$ & $\mathrm{M}$ & $\mathrm{M}$ \\
5 and 27 & $\mathrm{NP}$ & $\mathrm{NP}$ & $\mathrm{NP}$ & $\mathrm{NP}$ \\
ATCC 13048 & $\mathrm{~T}$ & $\mathrm{~T}$ & $\mathrm{~T}$ & $\mathrm{M}$ \\
\hline
\end{tabular}

ATCC 13048 (Table 3). The porins derived from strains 2 and ATCC 13048 exhibited the same critical temperature $\left(70^{\circ} \mathrm{C}\right)$ corresponding to complete transition from trimer to monomer form. In contrast, the porin from strain 3 was relatively heat-labile $\left(10^{\circ} \mathrm{C}\right.$ shift $)$, as the trimer-monomer transition threshold occurred at $60^{\circ} \mathrm{C}$ (Table 3). These observations suggested a misfolding of the functional trimer synthesized by strain 3 .

Immunodetection of OmpA, which plays a key role in the conservation of the membrane architecture, was always positive (Fig. 1, lower part), suggesting the absence of a general alteration impairing the outermembrane porin expression or assembly in these strains.

As these changes in porin content did not seem to be related to a general effect on outer-membrane protein synthesis, we investigated the possible role of OmpX. Expression of this outer-membrane protein has been reported to regulate porin synthesis negatively at a posttranscriptional level in E. cloacae (Stoorvogel et al., 1991). We identified OmpX expression by using immunological tools. No significant increase in OmpX synthesis was observed in the E. aerogenes strains devoid of porins (data not shown). This suggested that another regulatory step was involved in the porin deficiency phenotype.

\section{$\boldsymbol{\beta}$-Lactamase study}

To evaluate the contribution of cephalosporinase activity to resistance, the rate of nitrocefin hydrolysis was investigated with crude extracts of some clinical strains before and after induction with imipenem (Table 2). Strains 5 and 27 produced the highest basal levels of $\beta$ lactamase $\left[>1000 \mathrm{mU}(\mathrm{mg} \text { protein })^{-1}\right]$ while strain 2 had the lowest basal level $\left[<100 \mathrm{mU}(\mathrm{mg} \text { protein })^{-1}\right]$. With the exception of strains 2 and $19, \beta$-lactamase activity was inducible and the amount of derepressed $\beta$ lactamase reached a maximum level of $9000 \mathrm{mU}(\mathrm{mg}$ protein) $)^{-1}$ in strain 27.

\section{Quinolone susceptibility and efflux mechanism}

The MICs of quinolones (ofloxacin, norfloxacin, sparfloxacin), chloramphenicol and tetracycline were determined for the four E. aerogenes strains. They exhibited the same resistance pattern for chloramphenicol and a different resistance pattern for tetracycline, compared to strain ATCC 13048 as control (Table 4). The high MICs for quinolones pointed to the

Table 4. Susceptibility of the $E$. aerogenes strains to a range of structurally unrelated antibiotics

Values are means of three independent determinations.

\begin{tabular}{|lccccc|}
\hline $\begin{array}{l}\text { E. aerogenes } \\
\text { strain }\end{array}$ & \multicolumn{5}{c|}{ MIC $\left(\mu \mathrm{g} \mathrm{m}^{-1}\right)$} \\
\cline { 2 - 6 } & Chloramphenicol & Tetracycline & Norfloxacin & Ofloxacin & Sparfloxacin \\
\hline 2 & $>256$ & 4 & 128 & 128 & $>64$ \\
3 & $>256$ & 8 & 256 & 128 & 64 \\
5 & $>256$ & 4 & 128 & 128 & 64 \\
27 & $>256$ & 16 & 256 & $>128$ & $>64$ \\
ATCC 13048 & 16 & 2 & 0.5 & 0.5 & $0 \cdot 25$ \\
\hline
\end{tabular}




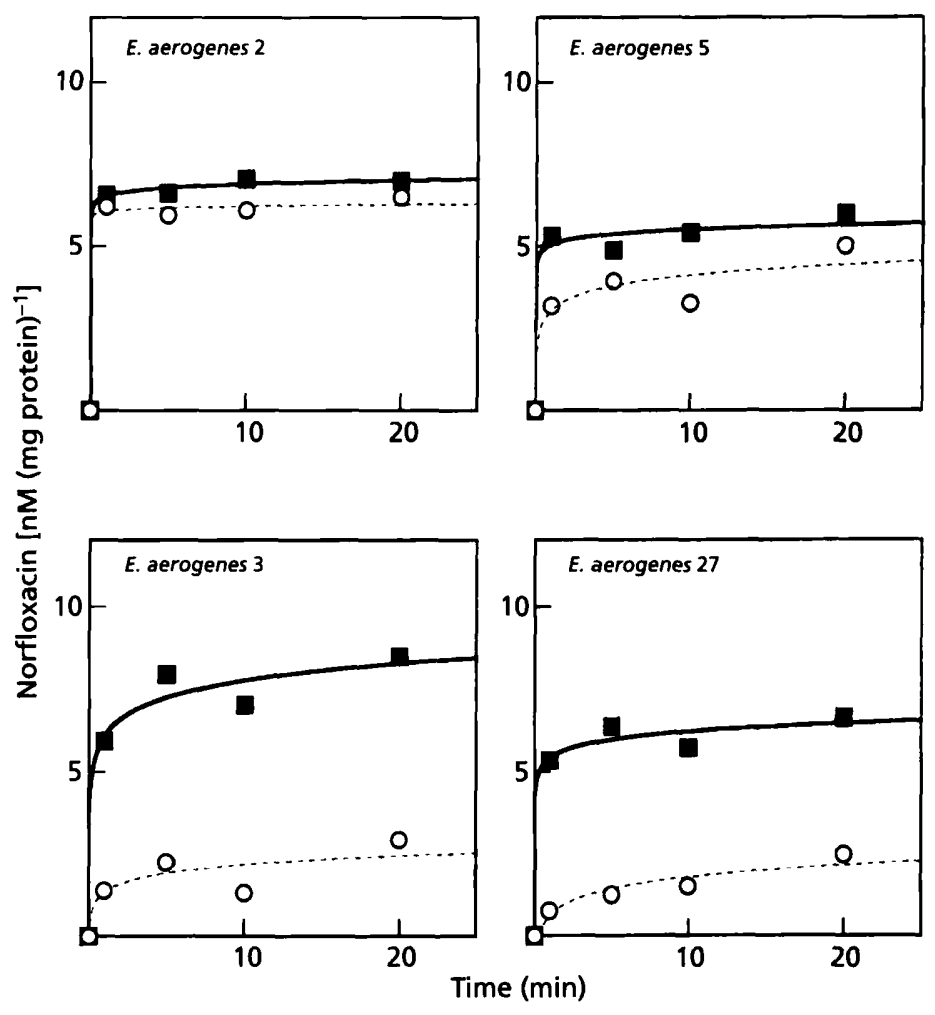

Fig. 2. Accumulation of $\left[{ }^{14} \mathrm{C}\right]$ norfloxacin by various $E$. aerogenes clinical isolates in the absence (circles and broken line) and presence (squares and continuous line) of CCCP.

presence of an active efflux. The intracellular accumulation of radiolabelled norfloxacin was consequently determined in these isolates. As the uptake of quinolones is energy-independent and efflux is energy-dependent (Cohen et al., 1988; Diver et al., 1990; Nikaido, 1996), the addition of an uncoupler (CCCP) during the incubation clearly revealed the role of an efflux pump in the intracellular accumulation of $\left[{ }^{14} \mathrm{C}\right]$ norfloxacin (Fig. 2). As regards strains 2 and 5, no significant change in the intracellular level of radiolabelled norfloxacin was noted in the absence or in the presence of CCCP. Consequently, the maximum intracellular levels of norfloxacin in strains 2 and 5 are similar to the maximum levels in strains 3 and 27 after CCCP treatment. In contrast, energy-dependent efflux was clearly evident in isolates 3 and 27 (Fig. 2). The addition of CCCP, which collapses the energy component of the efflux, blocked the pump and restored the intracellular norfloxacin concentration.

\section{DISCUSSION}

Antibiotic pressure leads to the emergence of strains with modified envelope characteristics (Bradford et al., 1997; Bush et al., 1985; Cornaglia et al., 1995; Lee et al., 1991), i.e. membrane impermeability or efflux mechanisms (Charrel et al., 1996; George et al., 1995; Hopkins \& Towner, 1990) and also increased basal level of cephalosporinase activity.

Three of the 27 E. aerogenes isolates tested here had high cefepime MICs. Strain 3 had a wild-type porin expression level. This could be an apparent discrepancy with a previous study (Charrel $e$ t al., 1996) in which a correlation was found between the $\beta$-lactam crossresistance index and changes in porin expression. Several teams have reported a dual effect of protein misfolding on porin conformational stability and pore function in the E. coli OmpC and OmpF porins (Fourel et al., 1993; Gokce et al., 1997; Jeanteur et al., 1994; Liu et al., 1997). This could explain the drastic fall in drug susceptibility in strain 3 , functionally mimicking the porin-deficient phenotype of isolates 5 and 27 . The failure of the $\beta$ lactamase inhibitor clavulanic acid to restore cephalosporin susceptibility, as observed in porin-deficient strains 5 and 27 , also points to an altered channel in strain 3. Alternatively, a mutation in a distinct outermembrane component necessary for the correct insertion of porins, such as lipopolysaccharide, may induce a marked mismatch (Leying et al., 1991). During the assembly step, steric hindrance could generate an abortive porin conformation in the membrane. Normal OmpA expression in all strains, which also requires correct lipopolysaccharide synthesis for efficient membrane insertion (Bolla et al., 1987), is in keeping with an alteration targeting porin expression or folding. In vivo, strain 3 appears to normally synthesize an inefficient porin which has reduced thermal stability of trimer conformation. An alternative hypothesis corresponds with the CCCP-sensitive efflux pump detected in this strain, which might contribute to the overall drug resistance (Nikaido, 1996).

Strain 27 was resistant to imipenem, with an MIC of $8 \mu \mathrm{g} \mathrm{ml}^{-1}$. This is in keeping with a previous report (Charrel et al., 1996) suggesting the existence of a 
pleiotropic alteration of outer-membrane channels that impairs the penetration of carbapenems and recent expanded-spectrum cephalosporins in these isolates. Thus, envelope permeability was altered in two ways in strain 27: through porin expression and efflux. It has been reported that some components of the regulation cascade of the Mdr system (Ariza et al., 1995; George, 1996; Nikaido, 1996; Okusu et al., 1996) can negatively regulate the expression of non-specific porins (Cohen $e t$ al., 1988; Gambino et al., 1993; George et al., 1995; Misra \& Reeves, 1987). Consequently, it is possible that some steps of the process activating quinolone efflux are also involved in the porin-deficient phenotype of strain 27. Such a proposition may be correlated with the description of similar regulatory elements in other species, such as robA in E. cloacae (Lee et al., 1996), ramA in Klebsiella pneumoniae (George et al., 1995), marA and rob in E. coli (Ariza et al., 1995; Cohen et al., 1988 ) or bacterial MarA homologues (Alekshun \& Levy, 1997).

The results of this study and a previous report (Charrel et al., 1996) suggest that the loss of entry channels is a bacterial response against cefepime and other new cephalosporins with configurations well-adapted to bacterial porins and stability to enzymic attack (Nikaido et al., 1990).

To our knowledge, this is the first description of such a complex resistance strategy in clinical isolates of $E$. aerogenes, including $\beta$-lactamase production, impermeability and active efflux. We have previously reported an association between porin deficiency and $\beta$-lactamase production, inducing a high level of drug resistance (Charrel et al., 1996); in this study, we observed the simultaneous regulation of 'in' and 'out' flux through the membrane via two different ways.

\section{ACKNOWLEDGEMENTS}

We gratefully acknowledge J. M. Bolla and A. Cremieux for helpful discussions. This work is supported by the Institut National de la Sante et de la Recherche Medicale, the Region PACA and Marseille-Metropole, and by a grant from BristolMyers Squibb.

\section{REFERENCES}

Acar, J., Bergogne-Berezin, E., Chardon, H. \& 12 other authors (1994). Statement of the antibiogram committee of the French Society for Microbiology (in insert). Pathol Biol 42, I-VIII.

Alekshun, M. N. \& Levy, S. B. (1997). Regulation of chromosomally mediated multiple antibiotic resistance: the mar regulon. Antimicrob Agents Chemother 41, 2067-2075.

Ariza, R. R., Li, Z., Ringstad, N. \& Demple, B. (1995). Activation of multiple antibiotic resistance and binding of stress-inducible promoters by Escherichia coli Rob protein. J Bacteriol 177, 1655-1661.

Arpin, C., Coze, C., Rogues, A. M., Gachie, J. P., Bebear, C. \& Quentin, C. (1996). Epidemiological study of an outbreak due to multidrug-resistant Enterobacter aerogenes in a medical intensive care unit. J Clin Microbiol 34, 2163-2169.
Bergogne-Berezin, E., Decre, D. \& Joly-Guillou, M. L. (1993). Opportunistic nosocomial multiply resistant bacterial infections, their treatment and prevention. J Antimicrob Chemother 32 (Suppl A), 39-47.

Bolla, J.-M., Lazdunski, C., Inouye, M. \& Pagès, J.-M. (1987). Export and secretion of overproduced OmpA- $\beta$-lactamase in E. coli. FEBS Lett 224, 213-218.

Bradford, P. A., Urban, C., Mariano, N., Projan, S. J., Rahal, J. J. \& Bush, K. (1997). Imipenem resistance in Klebsiella pneumoniae is associated with the combination of ACT-1, a plasmid-mediated AmpC $\beta$-lactamase, and the loss of outer membrane protein. Antimicrob Agents Chemother 41, 563-569.

Bush, K., Tanaka, S. K., Bonner, D. P. \& Sykes, R. B. (1985). Resistance caused by decreased penetration of $\beta$-lactam antibiotics into Enterobacter cloacae. Antimicrob Agents Chemother 27, 555-560.

Cassell, G. H. (1995). ASM task force urges broad program on antimicrobial resistance. ASM News 61, 116-120.

Charrel, R. N., Pagès, J.-M., De Micco, P. \& Mallea, M. (1996). Prevalence of outer membrane porin alteration in $\beta$-lactamantibiotic-resistant Enterobacter aerogenes. Antimicrob Agents Chemother 40, 2854-2858.

Cohen, S. P., McMurry, L. M. \& Levy, S. B. (1988). marA locus causes decreased expression of OmpF porin in multiple-antibiotic-resistant (Mar) mutants of Escherichia coli. J Bacteriol 170, 5416-5422.

Cornaglia, G., Russell, K., Satta, G. \& Fontana, R. (1995). Relative importance of outer membrane permeability and group $1 \beta$ lactamase as determinants of meropenem and imipenem activities against Enterobacter cloacae. Antimicrob Agents Chemother 39, 350-355.

Davin-Regli, A., Monnet, D., Saux, P., Bosi, C., Charrel, R., Barthelemy, A. \& Bollet, C. (1996). Molecular epidemiology of Enterobacter aerogenes acquisition: one-year prospective study in two intensive care units. J Clin Microbiol 34, 1474-1480.

Diver, J. M., Piddock, L. J. V. \& Wise, R. (1990). The accumulation of five quinolone antibacterial agents by Escherichia coli. $J$ Antimicrob Chemother 25, 319-333.

Emori, T. G. \& Gaynes, R. P. (1993). An overview of nosocomial infections, including the role of the microbiology laboratory. Clin Microbiol Rev 6, 428-442.

Fourel, D., Mizushima, S., Bernadac, A. \& Pagès, J.-M. (1993). Specific regions of Escherichia coli $\mathrm{OmpF}$ protein involved in antigenic and colicin receptor sites and in stable trimerization. $J$ Bacteriol 175, 2754-2757.

Gambino, L., Gracheck, S. J. \& Miller, P. F. (1993). Overexpression of the MarA positive regulator is sufficient to confer multiple antibiotic resistance in Escherichia coli. J Bacteriol 175, 28882894.

George, A. M. (1996). Multidrug resistance in enteric and other Gram-negative bacteria. FEMS Microbiol Lett 139, 1-10.

George, A. M., Hall, R. M. \& Stokes, H. W. (1995). Multidrug resistance in Klebsiella pneumoniae: a novel gene, $\operatorname{ram} A$, confers a multidrug resistance phenotype in Escherichia coli. Microbiology 141, 1909-1920.

Gibbons, A. (1992). Exploring new strategies to fight drugresistant microbes. Science 257, 1036-1038.

Gokce, I., Bainbridge, G. \& Lakey, J. H. (1997). Stabilising and destabilising modifications of cysteines in the $E$. coli outer membrane porin protein OmpC. FEBS Lett 411, 201-205.

Hopkins, J. M. \& Towner, K. J. (1990). Enhanced resistance to cefotaxime and imipenem associated with outer membrane 
protein alterations in Enterobacter aerogenes. I Antimicrob Chemother 25, 49-55.

Jeanteur, D., Schirmer, T., Fourel, D., Simonet, V., Rummel, G., Rosenbush, J. P. \& Pagès, J.-M. (1994). Structural and functional alterations of a colicin resistant mutant of OmpF from E. coli. Proc Natl Acad Sci USA 91, 10675-10679.

Lee, E. H., Nicolas, M.-H., Kitzis, M. D., Pialoux, G., Collatz, E. \& Gutmann, L. (1991). Association of two resistance mechanisms in a clinical isolate of Enterobacter cloacae with high-level resistance to imipenem. Antimicrob Agents Chemother 35, 1093-1098.

Lee, E. H., Collatz, E., Podglajen, I. \& Gutmann, L. (1996). A roblike gene of Enterobacter cloacae affecting porin synthesis and susceptibility to multiple antibiotics. Antimicrob Agents Chemother 40, 2029-2033.

Leying, H., Cullmann, W. \& Dick, W. (1991). Carbapenem resistance in Enterobacter aerogenes is due to lipopolysaccharide alterations. Chemotherapy 37, 106-113.

Liu, N., Benedik, M. J. \& Lakey, J. H. (1997). Disruption of polyamide modulation by a single a mino acid substitution on the L3 loop of the OmpC porin channel. Biochim Biophys Acta 1326, 201-212.

Ma, D., Cook, D. N., Alberti, M., Pon, N. G., Nikaido, H. \& Hearst, J. E. (1995). Genes $a c r A$ and $a c r B$ encode a stress-induced efflux system of Escherichia coli. Mol Microbiol 16, 45-55.

Mallea, M., Simonet, V., Lee, E. H., Collatz, E., Gervier, R., Gutmann, L. \& Pagès, J.-M. (1995). Biological and immunological comparisons of Enterobacter cloacae and Escherichia coli porins. FEMS Microbiol Lett 129, 273-280.

Misra, R. \& Reeves, P. R. (1987). Role of micF in the tolC-mediated regulation of OmpF, a major outer membrane protein of Escherichia coli K-12. J Bacteriol 169, 4722-4730.

Nikaido, H. (1996). Multidrug efflux pumps of Gram-negative bacteria. J Bacteriol 178, 5853-5859.
Nikaido, H., Liu, W. \& Rosenberg, E. Y. (1990). Outer membrane permeability and $\beta$-lactamase stability of dipolar ionic cephalosporins containing methoxyimino substituents. Antimicrob Agents Chemother 34, 337-342.

Nogami, T., Mizuno, T. \& Mizushima, S. (1985). Construction of a series of ompF-ompC chimeric genes by in vivo homologous recombination in Escherichia coli and characterisation of the translational products. J Bacteriol 164, 797-801.

Okusu, H., Ma, D. \& Nikaido, H. (1996). AcrAB efflux pump plays a major role in the antibiotic resistance phenotype of Escherichia coli multiple-antibiotic-resistance (Mar) mutants. J Bacteriol 178 , 306-308.

Rice, L. B., Carias, L. L., Etter, L. \& Shlaes, D. M. (1993). Resistance to cefoperazone-sulbactam in Klebsiella pneumoniae: evidence for enhanced resistance resulting from the coexistence of two different resistance mechanisms. Antimicrob Agents Chemother 37, 1061-1064.

Simonet, V., Mallea, M., Fourel, D., Bolla, J.-M. \& Pagès, J.-M. (1996). Crucial domains are conserved in Enterobacteriaceae porins. FEMS Microbiol Lett 136, 91-97.

Stoorvogel, J., van Bussel, M. J. \& van de Klundert, J. A. M. (1991). Biological characterization of an Enterobacter cloacae outer membrane protein (OmpX). J Bacteriol 173, 161-167.

Thornsberry, $C$. (1995). Trends in antimicrobial resistance among today's bacterial pathogens. Pharmacotherapy 15, 3S-8S.

Vincent, J. L., Bihari, D. J., Suter, P. M., Bruining, H. A., White, J., Nicolas-Chanoine, M.-H., Wolff, M., Spencer, R. C. \& Hemmer, M. (1995). The prevalence of nosocomial infection in intensive care units in Europe. JAMA 274, 639-644.

Received 13 May 1998; revised 27 July 1998; accepted 7 August 1998. 